\title{
ENZYMATIC ACTIVITY OF THE SILKWORM, BOMBYX MORI L. HEAMOLYMPH REARED ON DIFFERENT MULBERRY VARIETIES
}

\section{MAHMOUD, SOUAD M. ${ }^{1}$, AKILA M. EL-SHAFEI ${ }^{2}$, A. A. MOUSTAFA ${ }^{3}$, A. A. EL-BANNA ${ }^{4}$ and MARWA N. MOUSTAFA ${ }^{5}$}

1. \& 5. Sericulture Research Department, Plant Protection Research Institute - ARC, Dokki, Giza

2. \& 4. Department of Entomology, Faculty of Science, Ain Shams University, Cairo.

3. Biochemistry Department, Faculty of Agriculture, Cairo University.

(Manuscript received 29 May 2013)

\begin{abstract}
The effect of feeding the silkworm Bombyx mori L. on six different mulberry variety (Morus alba var. Kokuso-27, Sh2 x Lunlog, Kaeryang- ppong, Kanava-2, Leavigata, and Morus nigra var. Arandaly) on some enzymatic activities which affect silk production was studied 3-Phosphoglycerate Dehydrogenase (3PGD, Glutamic Oxaloacetic Transaminase (GOT) and Glutamate Pyruvic Transaminase (GPT) which play a vital role in the synthesis of silk protein were determined.

Results indicated that feeding silkworm larvae on Morus alba var. Kokuso-27 represented the highest rate of 3-PGD activity (6.14 $\mathrm{u} / \mathrm{mg}$ ) followed by $\mathrm{Sh}_{2} \mathrm{xLunlog}$ variety $(5.76 \mathrm{u} / \mathrm{mg}$ ) and Arandaly (4.2 u/mg) while, slight differences in 3-PGD activity was found between the other three varieties. The same with GPT enzyme, the mulberry varieties Morus alba var Kokuso-27 followed by $\mathrm{Sh}_{2}$ xLunlong fed to larvae resulted in a high rate $(5.21,4.38 \mathrm{U} / \mathrm{L})$, respectively. However, Kanava-2 recorded higher value of GOT followed by Leavigata ( 11.16 and $9.82 \mathrm{U} / \mathrm{L}$ ), respectively
\end{abstract}

\section{INTRODUCTION}

The development of silk industry largely depend upon the use of improved breeds of silkworm, the production of quality leaves through better mulberry varieties and methods of rearing (Tayade and Jawale 1984). The silkworm Bombyx mori L. is highly specialized phytophagous insect as it feeds only mulberry leaves.

It's known that "many if not all, of the heamolymph proteins are enzymes and doubtless play a role in the economy of insects" (Laufer, 1960). In Bombyx mori L. silkworm, the variable growth rate of organs is clearly reflected during development and differentiation. Differential growth varies depending upon the genetic endowment of the race apart from quality and quantity of food intake and climatic conditions (Maribashetty and Reddy, 1998). Simultaneously, the cellular structures of silk gland also differentiate and repair themselves for synthesis of silk proteins by utilizing the free amino acids present in the heamolymph (Horie et al.,1978, Mathur et al., 1989). 
The important amino acids that take part in the biosynthesis of silk have been determined to be glycine, alanine, tyrosine and serine which are present in the heamolymph in variable portions.

Most of the amino acids requirements for the biosynthesis of silk are served by fat body through the heamolymph which plays an important role in transportation and maintains a delicate equilibrium of free amino acids during the metabolic activities (Wyatt, 1961).

Transamination reaction plays a leading role in the synthesis of silk amino acids, among the numerous enzymes, which reversibly catalyze the transfer of an amino group from an amino to an a- Keto acid, there are aspartate amino transferase (Glutamate Oxaloacetate Transaminase) and alanin amino transferase (Glutamate Pyruvate Transaminase) (Wilkinson.,1965). Aminotransferase is involved in the uptake of nitrogen from mulberry leaves by body tissues and silk glands which resulted in subsequent promotion of silk protein synthesis as suggested by (Li and Zhu 1985).

The present study is an attempt to analyze the Glutamic - Oxaloacetic Transaminase (GOT), Glutamic Pyruvic Transaminase (GPT) and specific activity of 3Phospheglycerate Dehydrogenase enzyme in the haemolymph and to correlate it with the food sources of the silkworm and the effect of feeding different mulberry varieties on synthesis of silk.

\section{MATERIALS AND METHODS}

\section{a- Silkworm rearing:}

Silkworm eggs of the univoltine race (S.A.105) was obtained from the Sericulture Research Department (SRD) of Plant Protection Research Institute (PPRI).and reared at the same department from hatching till cocoon formation according to the standard methodology of rearing in SRD. Rearing was carried out during two successive spring seasons of 2010 and 2011 under laboratory conditions ( $28 \pm 2{ }^{\circ} \mathrm{C}$ and R.H. 80\%). Removal of fecal matter, diseased larvae and bed cleaning was done at regular intervals.

Larvae were divided into six groups each group was fed on one of the following fresh mulberry varieties four times a day:

Morus alba var. Kokuso-27 imported from Japan.

Morus alba var. Leavigata imported from Pakistan.

Morus alba var .Kanava-2 imported from India.

Morus alba var. Kaeryang-ppong imported from North Korea.

Morus alba var. Sh2 x Lunlog imported from China.

Morus nigra var. Arandaly (native) 


\section{b- Preparation of haemolymph samples:}

Haemolymph of each group was collected by punctured pro-abdominal leg of five larvae per replicates in $6^{\text {th }}$ day of the fifth instar larvae in a glass tubes with a thin film of crystalline phenil thio-urea (a tyrosinase inhibitor), tubes were deep freezed at $-20^{\circ}$ C. Each group contain three replicates and each tube contains heamolymph of 5 larvae, heamolymph samples were centrifuged (2500 rpm for 6 minutes).

\section{c- Determination of Transaminase Enzymes (GOT \&GPT):}

Aspartate Amino Transferase (AST) or Glutamate Oxaloacetate Transaminase (GOT) and Alanine Amino Transferase (ALT) or Glutamate Pyruvate Transaminase (GPT) activities were measured colorimetrically in haemolymph at $505 \mathrm{~nm}$ using a standard curve according to the method described by Reitman and Frankel (1957).

\section{d- Determination of 3-Phosphoglycerate Dehydrogenase Enzyme:}

The centrifuged samples and the aliquots of the supernatants were used to estimate the activity of 3-Phosphoglycerate Dehydrogenase enzyme by employing spectrophotometric method described by Willis and Sallach (1964) and measured at A340 nm.

\section{RESULTS AND DISCUSSION}

The changes in the activity of the three enzymes GOT, GPT and 3Phosphoglycerate Dehydrogenase (3-PGD) of S.A.105 heamolymph were determined in the six groups in table (1).

Table 1. Biochemical analysis of (Transaminases(GPT \& GOT) and 3Phosphoglycerate dehydrogenase) enzymes in heamolymph of $5^{\text {th }}$ instar larvae of silkworm race fed on six mulberry varieties during spring season.

\begin{tabular}{|c|c|c|c|c|c|c|c|}
\hline \multirow{2}{*}{ Treatment } & \multicolumn{7}{|c|}{ Mulberry Varieties } \\
\hline & $\begin{array}{l}\text { Kokuso- } \\
27\end{array}$ & $\mathrm{Sh}_{2}$ xlulog & Arandaly & $\begin{array}{l}\text { Kearyang- } \\
\text { ppong }\end{array}$ & $\begin{array}{l}\text { Kanava- } \\
2\end{array}$ & Leavigata & L.S.D \\
\hline $\begin{array}{c}\text { Glutamic pyruvic } \\
\text { Transaminase } \\
(\mathrm{U} / \mathrm{L})\end{array}$ & $\begin{array}{l}5.21 \text { a A } \\
\pm 0.69\end{array}$ & $\begin{array}{l}4.38 \mathrm{aA} \\
\pm 0.57\end{array}$ & $\begin{array}{l}3.67 \mathrm{bA} \\
\pm 0.57\end{array}$ & $\begin{array}{l}3.26 \mathrm{bA} \\
\pm 0.60\end{array}$ & $\begin{array}{l}3.83 \mathrm{bA} \\
\pm 0.57\end{array}$ & $\begin{array}{l}3.11 \mathrm{bA} \\
\pm 0.64\end{array}$ & 1.887 \\
\hline $\begin{array}{c}\text { Glutamic } \\
\text { Oxaloacetic } \\
\text { Transaminase } \\
(\mathrm{U} / \mathrm{L})\end{array}$ & $\begin{array}{l}7.36 \text { a C } \\
\pm 0.75\end{array}$ & $\begin{array}{l}8.24 \mathrm{bBC} \\
\pm 0.57\end{array}$ & $\begin{array}{l}7.81 \mathrm{aBC} \\
\pm 0.58\end{array}$ & $\begin{array}{l}8.65 \mathrm{aBC} \\
\pm 0.95\end{array}$ & $\begin{array}{l}11.16 \\
\mathrm{aA} \\
\pm 0.48\end{array}$ & $\begin{array}{l}9.82 \mathrm{aBA} \\
\pm 0.91\end{array}$ & 2.253 \\
\hline $\begin{array}{c}3- \\
\text { Phosphoglycerate } \\
\text { dehydrogenase } \\
(\mathrm{U} / \mathrm{mg}) \\
\end{array}$ & $\begin{array}{l}6.41 \text { a A } \\
\pm 0.58\end{array}$ & $\begin{array}{l}5.76 \text { b A } \\
\pm 0.60\end{array}$ & $\begin{array}{l}4.82 \mathrm{bA} \\
\pm 0.57\end{array}$ & $\begin{array}{l}3.67 \mathrm{~b} \mathrm{~A} \\
\pm 0.88\end{array}$ & $\begin{array}{l}3.56 \mathrm{~b} \mathrm{~A} \\
\pm 0.57\end{array}$ & $\begin{array}{l}3.82 \mathrm{bA} \\
\pm 1.05\end{array}$ & 2.926 \\
\hline L.S.D & 2.349 & 2.025 & 2.004 & 2.859 & 1.897 & 3.059 & \\
\hline
\end{tabular}

Each value represents the mean $\pm \mathrm{SE}, \mathrm{n}=3$.

$a, b, c, d$ Values are means of three replicates $\pm S E$, numbers in the same column followed by the same letters are not significant different at $<0.05$ percentage . 
Fig. 1. Biochemical analysis of (Transaminases(GPT \& GOT) and 3-Phosphoglycerate dehydrogenase) enzymes in heamolymph of $5^{\text {th }}$ instar larvae of silkworm race fed on six mulberry varieties during spring season.

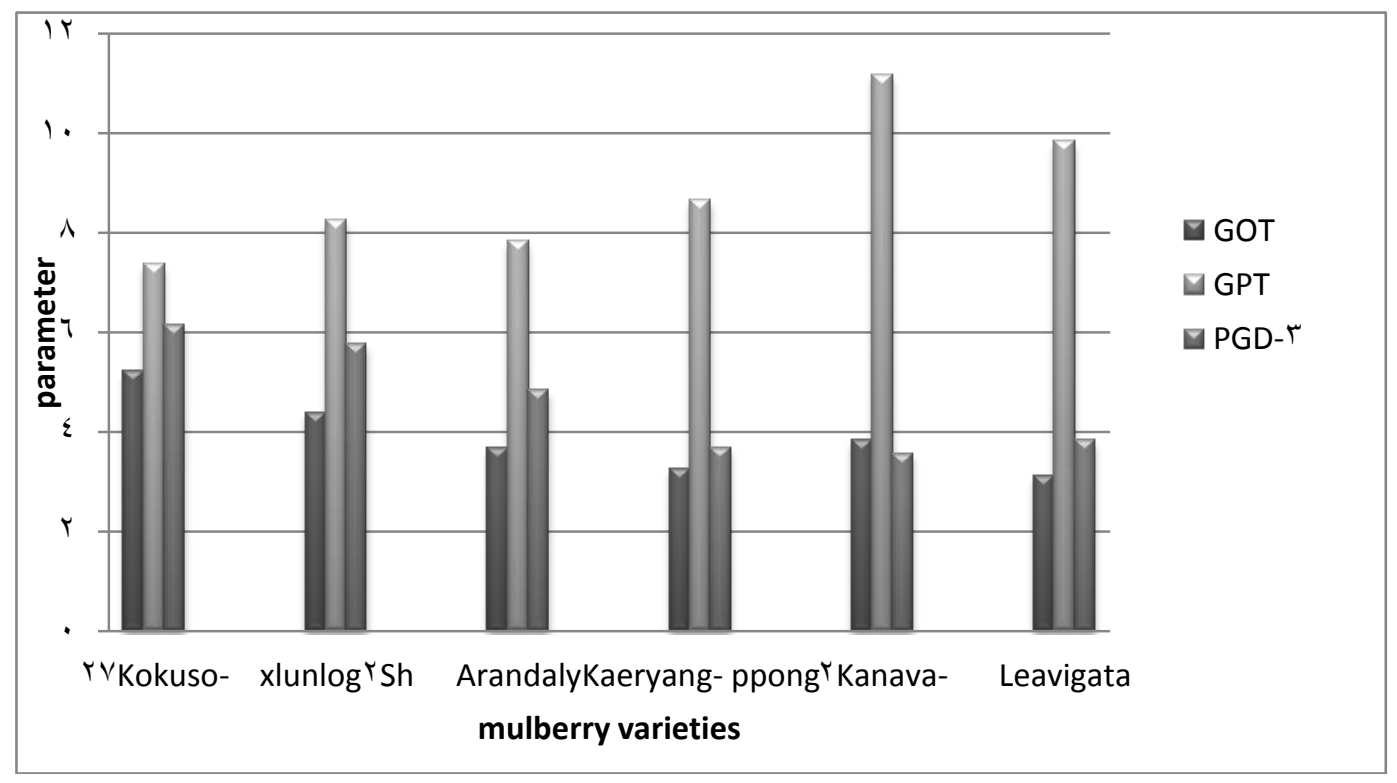

\section{A-Transaminase Enzymes:}

The activity of both GOT and GPT was different in B. mori L. heamolymph of $5^{\text {th }}$ instar larvae.

Results shown in the Table (1) revealed that GOT activities were higher than GPT activities in the haemolymph of all different groups.

In addition, data presented in the Table (1) indicated that different mulberry varieties affect transaminases enzyme activities in the haemolymph of $B$. mori L. $5^{\text {th }}$ instar larvae, however without significant difference between mulberry varieties in GOT and GPT activities.

GOT activity of larvae fed on Morus alba var. Kanava-2 recorded the high value (11.16 U/L) followed by Morus alba var. Leavigata (9.82U/L). While Morus nigra var. Arandally and Morus alba var. Kokuso-27 showed the least values (7.81 and 7.36 $\mathrm{U} / \mathrm{L})$, respectively.

On the other hand, GPT enzyme of larvae fed on, Morus alba var. Kokuso-27 recorded a higher value of $(5.21 \mathrm{U} / \mathrm{L})$, while those fed on Morus alba var. Leavigata was the least (3.11 U/L). Similar results were reported by (Singh, 2010) in Philosamia ricini silkworm (96.5 and $24.4 \mathrm{u} / \mathrm{mg}$ protein) for GOT and GPT, respectively, (Lakshmi Velide, 2012) came to the same conclusion in Antheraea mylitta silkworm and determined the activities of the two transaminases GOT and GPT (98.7 and $26.4 \mathrm{u} / \mathrm{mg}$ protein), respectively.

Both these major transaminases are concerned with amino group transfer. Transamination has been demonstrated in a number of insect tissues, particularly that concerning glutamate, aspartate and alanine (Glimour, 1961). Aspartatic- a glutamic transaminase was detected in the haemolymph and some other tissues of $B$. mori $\mathrm{L}$. 
larvae (Bheemeswar and Sreenivasaya, 1952). Singh (2010) suggested that GOT and GPT might lead to the supply of the precursors for the Krebs cycle towards generation of energy, as it is known that many amino acids and metabolites can lead to pyruvate production.

\section{B- 3-Phosphoglycerate Dehydrogenase}

Measurement of 3-Phosphoglycerate Dehydrogenase (3-PGD) activity was performed with spectrophotometric procedure. There is no significant differences were detected between the tested groups. As shown in the Table (1), the activity of (3PGD) recorded $\left(6.14,5.76,4.82,3.67,3.56\right.$ and3.82 U/mg) for Kokuso-27, $S_{2} x L u n l o g$, Arandally, Kaeryang -ppong, kanava-2 and Leavigata, respectively.

The silkworm requires altogether eighteen amino acids ten essential, five nonessential, one semi-essential and two acidic (Maribashetti and Reddy, 1998) for its normal growth and development. Among the five non-essential amino acids, glycine, alanine, and serine in the ratio of $3: 2: 1$, consistituting nearly $60 \%$ of silk proteins form the crystalline fraction of fibroin. Further, these three amino acids are inter convertible and synthesized rapidly from aspartate or glutamate by transamination and grouped into one category. The increase specific activity of 3PGD in the haemolymph samples collected from larvae fed on Kokuso- 27 and $\mathrm{Sh}_{2} \mathrm{xLunlong}$ indicate enhanced rate of metabolism of the non-essential free amino acids.

Since the synthesis of these three non-essential amino- acids depends on the activity of the enzyme 3-PGD, it is reasonable to quantify and correlate the specific activity of this enzyme with silk productivity of the silkworm through enhancement of its food quality.

The importance of quality of mulberry leaves on growth, development, health and silk production in $B$. mori L. was stressed by many researcher, as different varieties of mulberry may have compositional differences and might lead to varying effects on growth and silk production (Yokoyama, 1963, Das and Sikdar, 1970, Krishnaswami et al., 1971, Radha et al.,1978 and Mahmoud, 2000).

From the present study it might be concluded that the variation in the transaminases GOT, GPT and 3- PGD activities in silkworm haemolymph depending on feeding different mulberry varieties can be attributed to mulberry compositional constituents and can help in choosing the elite varieties for improving silk production.

\section{REFERENCES}

1. Bheemeswar, B. and M. Sreenivasaya. 1952). Occurrence of transaminase in the Silkworm, Bombyx mori L. Current Sci. India 21, 253-255. Cited from Chem. Abstract 48, 895 (1954).

2. Das, B.C. and A.K. Sikdar. 1970. Evaluation of some improved strains of mulberry by feeding experiment. Indian J. seric., 9: 26-30. 
3. Horie Y., Inokuchi and K. Watanabe. 1978. Quantitative study of food utilization by the silkworm, Bombyx mori L. through its life cycle. II- Economy of nitrogen and amino acids. Bull. Sericult. Exp. Sta. 27(5):571-578.

4. Krishnaswami S., S. Kumararaj, K. Vijayaragavan and K. Kasiviswanathan. 1971. Silkworm feeding trials for evaluating the mulberry leaves as influenced by variety, spacing and nitrogen fertilization. Indian J. Seric., 10 (1):79-89.

5. Lakshmi Velide. 2012. Studies on biochemical components of the larval haemolymph, fat body and silkgland of tropical tasar silkworm, Anthereae mylitta Drury (Daba T.V) under cold stress condition. Euro. J. Exp. Bio., 2012, 2 (6):2238-2242.

6. Laufer H. 1960. studies of changes in enzymatic activities of blood proteins in the developing silk moth. Proc. Inter. Cong. Entom. IIth, Vienna III, 194-200.

7. Li, X. Y. and O. X. Zhu. 1985. Mechanisms of silk increase in Silkworm by $\mathrm{N}^{15}$ urea administration. Sci. Sericult. , 9 (4): 209-213.

8. Mahmoud Souad, M. 2000. Feeding Effect of Five Mulberry Varieties on the Silkworm, Bombyx mori L. Egypt. J. App. Sci. 15 (6): 253-261.

9. Maribashetty, V. G. and G. S. Reddy. 1998. Activity of 3- phosphoglycerate dehydrogenase in certain races of the silkworm, Bombyx mori L. Indian J. Seric. .37(2): 180-182.

10. Mathur, S.K., Roy A.K., Sen S.K. and G. Subba Rao. 1989. Studies on the growth of silkworm, Bombyx mori L. (Lepidoptera : Bombycidae) under tropical conditions. Indian J. Seric., 28 (1):71-79.

11. Radha, N.V., S. Letchoumanane, R. Sundarababu and S. Oblisami. 1978. Effect of feeding with the leaves of different mulberry varieties on races of silkworm. Symp. Seric. Sci., Bangalore ( Abst.), p.52.

12. Reitman, S. and S. Frankel. 1957. A colorimetric method for the determination of serum glutamic oxaloacetic and glutamic pyruvic transaminases. Ann. J. Clin. Path, 28 (56):56.

13. Singh, A. 2010. Low temperature induced alterations in certain biochemical constituents of $5^{\text {th }}$ instar larvae of Philosamia ricini (Lepidoptera: Saturinidae). Insect Physiol.:11-16.

14. Tayade, D.S. and M.D. Jawale. 1984. Studies on the Comparative performance of silkworm races against different varieties of mulberry under Marathwada conditions. Sericologia, 24(3):361-364.

15. Wilkinson, J. H. 1965. Isoenzyme. Chapman and Hall LTD, 11 New Fetter Lane., London, PP: 224.

16. Willis, J. E. and H. J. Sallach. 1964. Biochimica et Biophysica Acta 81:39-54.

17. Wyatt, G. R. 1961. The biochemistry of insect heamolymph. Ann. Rev. Entomol., 6: 75-102. 


\section{Bombyx mori L. النشاط الإنزيمى لهيموليمف دودة الحريز التوتية المرباه على أصناف مختلفة من أوراق التوت}

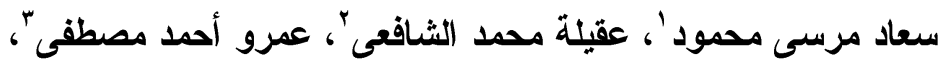

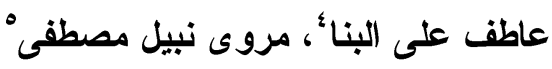

$$
\begin{aligned}
& \text { ا\&ه قسم بحوث الحربي، معه وقاية النباتات، مركز البحوث الزراعية ، القاهرة. }
\end{aligned}
$$

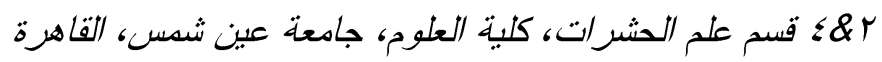

$$
\begin{aligned}
& \text { r قسم الكبيلياء الحبوية، كلية الزراعه، جامعة القاهرة }
\end{aligned}
$$

تم دراسة تأثير تغذية دودة الحرير التونية على ستة أصناف مختلفة من أوراق التوت(يابانى، صينى،كورى، هندى، عمانى، أرندلى) على نشاط بعض الإنزيمات التى تؤثر على إنتاج الحرير

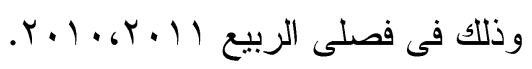

تم تقدير نشاط إنزيم ب-فوسفوجليسيرات ديهيدروجينيز ،إنزيم جلوتامات أوكسالو أسينك تزانس أمينيز و إنزيم جلوتامات بيروفبك تز انس أمينيز و التى تلعب دور حيوى فى تخليق بروتينات الحرير .

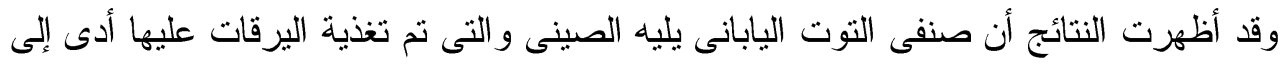

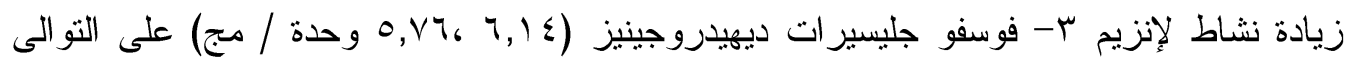

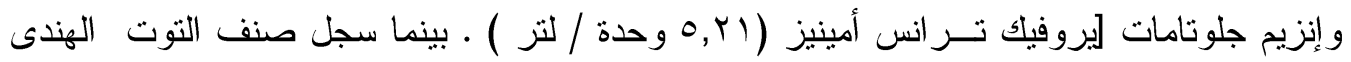

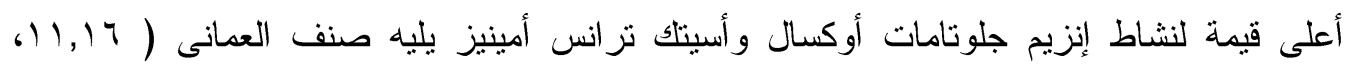

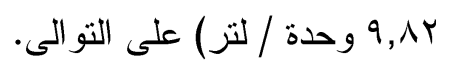

